\title{
Entrepreneurial Challenges Among Youth - with Special Reference to Sivagangai and Ramanathapuram Districts in Tamil Nadu
}

\author{
C. Vethirajan, S. Chandrasekar, MK.Ganeshan
}

\begin{abstract}
The Indian economy requires strong growth, empowered by youth, and this can be done by channelizing their creative skills and energy toward successful business ventures. In Tamil Nadu, the Tamil Nadu Adi Dravidar Housing and Development Corporation Limited (TAHDCO) scheme was incorporated in 1974 under the Companies Act of 1956. The objective of the scheme was to improve the socio-economic status of SCs/STs in Tamil Nadu. TAHDCO introduced a scheme in every district, especially meant for marginalized people from a low socio- economic background, to enhance entrepreneurship. This scheme offers financial assistance with subsidies to support entrepreneurship, in addition to training programmes that help start and sustain small businesses. The Self-Employment Programme for Youth (SEPY) under the TAHDCO scheme focuses on youth in the age group 18-35.To have a lasting impact, the promotion of youth entrepreneurship is to be approached comprehensively, emphasizing sectors with job creation potential and integrating the three components of sustainable enterprises social, economic and environmental.
\end{abstract}

Keywords: TAHDCO, SEPY, Entrepreneurship, Economic Development and Environmental Sustainability.

\section{INTRODUCTION}

India is rated as the world's 12th largest economy. The economic Liberalization in 1991 revolutionized business in India, and let the Indian economy grow to become one of the world's best. It also brought forth a host of entrepreneurs who generated millions of jobs. According to a UN Report (2014), the world's largest youth population with 356 million (10 to 24 years old) is in India. The 2011 Census Report indicates that around $41 \%$ of the population of India is below the age of $20,50 \%$ is in the 20-59 age groups, and the remaining $9 \%$ above the age of 60 . At the same time, only $32 \%$ of the country's youth (15-24 years) population is employed (World Development Indicator, World Bank Data 2014), which is far below the $41 \%$ global average. On the other hand, according to the NSSO (National Sample Survey Organization, 2016), figures at every level of education indicate that the unemployment rate is higher among the 15 to 29-year-old age group, as compared to the broader population as a whole.

Revised Manuscript Received on December 5, 2019.

Dr. C. VETHIRAJAN *, Professor and Head, Department of Corporate Secretaryship, School of Management, Karaikudi, TamilNadu, India. Email: drvethirajan@gmail.com,vethirajanc@alagappauniversity.ac.in

Dr.S.CHANDRASEKAR, Assistant Professor, Department of Commerce, Madura College (Autonomous), Madurai, TamilNadu, India. Email: anandhachandra@gmail.com

Mr.MK.GANESHAN, Alagappa Institute of Management, School of Management, Karaikudi, TamilNadu, India. Email: mkganeshanmba@gmail.com
The annual population growth rate of India is $1.2 \%$ (World Bank data, 2015), and a report from the United Nations Development Programme (UNDP), released in April 2016, showed that India will face a serious challenge of finding jobs for a growing population over the next 35 years. The Indian economy requires strong growth, empowered by youth, and this can be done by channelizing their creative skills and energy toward successful business ventures. In Tamil Nadu, the Tamil Nadu Adi Dravidar Housing and Development Corporation Limited (TAHDCO) scheme was incorporated in 1974 under the Companies Act of 1956. The objective of the scheme was to improve the socio-economic status of SCs/STs in Tamil Nadu. TAHDCO introduced a scheme in every district, especially meant for marginalized people from a low socio- economic background, to enhance entrepreneurship. This scheme offers financial assistance with subsidies to support entrepreneurship, in addition to training programmes that help start and sustain small businesses. The Self-Employment Programme for Youth (SEPY) under the TAHDCO scheme focuses on youth in the age group 18-35.To have a lasting impact, the promotion of youth entrepreneurship is to be approached comprehensively, emphasizing sectors with job creation potential and integrating the three components of sustainable enterprises social, economic and environmental.

\section{NEED FOR AND IMPORTANCE OF THE STUDY}

This particular area is being studied to understand how to engage rural youth in meaningful and productive ventures. The reasons for undertaking this study include the following:

A lack of opportunities: Owing to a lack of opportunities, educated youth face problems like unemployment and under-employment head-on. Further, medium and largescale private or public industries are in no way concerned about the difficulties confronted by this group.

A lack of capital: A lack of capital in the initial stages to set up an enterprise, coupled with little recognition of young people willing to take on the risks of a business venture, causes the youth to think twice about risking it. To add to their woes, there is a lack of thrust directed towards youngsters (by banks, micro-finance institutions, private moneylenders and proponents of related programs and schemes), and it results in their becoming in efficient entrepreneurs.

A lack of parental guidance: The young are not being engaged in productive and meaningful work, in part on account of the ignorance of the parents comprising the community.

A lack of skills and technical knowledge: Rural 
youth lack skills and technical knowledge, especially in business. Given that their background and economic pursuits are driven by agriculture and allied activities, they lack entrepreneurial skills.

A lack of funding: There are few funding opportunities for promoting enterprises initiated by the youth. Further, the state lacks institutions for skill development and vocational training.

A lack of implementation: Government schemes and programmes for the development of entrepreneurship have not been properly implemented. Entrepreneurship is a priority of the National Youth Policy 2014, with rural youth as a target group.

This study will help enhance the potential of the youth for entrepreneurship, thereby making them responsible for their own growth and development.

\section{Statement Of The Problem}

Much of India's population lives in villages. It is necessary, therefore, to focus on the development of villages in order to register a quantum leap in economic growth. There is a real "fear of failure" that stops rural youth from starting new businesses. In addition, youngsters seem to have lost faith in the government, with frequent changes in policies a regular affair. First-time entrepreneurs find it difficult to obtain finance for working capital. There is a lot of potential in rural areas that needs to be tapped, and this can be achieved by actively promoting rural entrepreneurship. It is, however, rather doubtful that today's youth will take to business as a full-time career in the future, against the backdrop of circumstances such as these:

A lack of technical knowledge and social capital adversely affects young entrepreneurs, and keeps them from reaping the benefits of government schemes.

Inaccessibility to institutions and the services of government and non-government organizations poses a threat to the youth in initiating and sustaining self-driven enterprises.

Hence, a study of the challenges faced by the youth will help the government implement new schemes for their economic development.

\section{Research Questions}

Based on the gaps in past studies and on the focus of the research problem, the following research questions were framed:

How far are youth interested in entrepreneurial activities?

What are the challenges they face as entrepreneurs?

Do they receive sufficient support from the government, NGOs and family?

What are the strategies used by the youth to develop entrepreneurship?

How are they able to sustain their livelihood and provide opportunities to others?

\section{Objectives Of The Study}

This study aims to describe the profile of youth entrepreneurs;

To assess the attitude and interest towards entrepreneurship among the youth;

To ascertain the extent of awareness about the TADHCO scheme among youth entrepreneurs;

To assess the support system from the government, NGOs and family; and

To identify strategies used by the youth to develop and sustain their entrepreneurship.

Implications of this study:

This study will help us understand the views and attitudes of young people with regard to the challenges they face as entrepreneurs. Furthermore, the study will explore the different areas and factors which influence and motivate young people to engage in meaningful and worthwhile livelihood promotional activities. The study will also assist banks and microfinance institutions to have confidence in new entrepreneurs and provide them with the much- needed financial support.

\section{METHODOLOGY}

Research Method and Design:

The quantitative method with a descriptive research design was used for the study. This method enabled the researchers to gather numerical and descriptive data to assess the relationship between the variables, and produce statistical information on the challenges faced by young entrepreneurs in sustaining a livelihood. Based on this design, the aim of the study was to describe the strategies used and challenges faced by rural youth entrepreneurs in the community, and the difficulties involved in sustaining a livelihood.

\section{Field of Study:}

This research study was conducted in two rural and semiurban sites in Tamil Nadu which have young and growing entrepreneurs who have benefited from government schemes. The two sites were chosen to ascertain the availability of resources and the proper utilization of entrepreneurship schemes through which rural youth have improved the quality of their lives. The study was conducted in Ramanathapuram and Sivagangai districts of Tamil Nadu, among youth entrepreneurs in the age group 18 to 35 , who were beneficiaries of the SEPY (Self-Employment Programme for Youth) of TAHDCO.

Population and Recruitment:

The TAHDCO scheme focuses on beneficiaries of all age groups, but the researchers have confined this research to the youth population (18-35 years) of SEFY beneficiaries (Self-Employment For Youth) under the TAHDCO scheme. There were 286 SEFY beneficiaries in both Ramanathapuram and Sivagangai districts, as per the list collected from the TAHDCO office.

\begin{tabular}{|l|l|l|}
\hline $\begin{array}{l}\text { Name of the study } \\
\text { site }\end{array}$ & $\begin{array}{l}\text { Total population of } \\
\text { SEPY beneficiaries }\end{array}$ & $\begin{array}{c}\text { Studied } \\
\text { population }\end{array}$ \\
\hline Ramanathapuram & 163 & 134 \\
\hline Sivagangai & 123 & 121 \\
\hline Total & 286 & 255 \\
\hline
\end{tabular}


Census Method of Enquiry:

The population size of the study was 286 , and the study used the census method of enquiry, wherein all the units in a particular population are taken for the study, and information gathered from every individual. A census, in simple terms, can be defined as a set of data collected from people in an area and presented in a comparable form (ratio or percentage). A census can be taken as a process by which the required data of all the people in a region is collected, compiled and published in a limited time span. In this study, the census data of TAHDCO beneficiaries of Sivagangai and Ramanathapuram districts was collected from the district TAHDCO office. Out of the total population of 286, data collected from 255 was used for the study. This was because of factors such as the non-availability of the respondents, unwillingness on their part to participate in the research, and the researchers' inability to trace the rest.

Survey Tools: The tool used for data collection was a structured interview schedule consisting of both open- and closed-ended questions, which enabled the researchers to identify the challenges and sustainability of youth entrepreneurs. The tool covered the following domains: (1) Demographic details of the respondents; (2) A profile of the entrepreneurship unit; (3) Attitude to and knowledge of the entrepreneurship; (4) Awareness of and challenges involved in the TAHDCO scheme; (5) Strategies used by youth entrepreneurs; (6) Availability of support systems (7) Entrepreneurship development programmes, and Sustainability of the entrepreneurship livelihood.

Source of Data:

The researchers used both primary and secondary data to examine the objectives of the study. Primary data was collected from youth entrepreneurs through the interview schedule. Secondary data was collected from books, economic surveys, government reports and periodicals, articles, newspapers, online journals and related research studies.

\section{DISCUSSION}

Socio-demographic details of the respondents: The socioeconomic background of young entrepreneurs acts as a base for entrepreneurial and skill development (Ahmed \& Kakoly, 1993). Social factors relating to family and community have a bearing on entrepreneurship, while economic factors act as a base for the financial support needed to develop entrepreneurship (Patel, 1995). The socio-demographic details of the respondents show that $53 \%$ were from Ramanathapuram and $47 \%$ from Sivagangai districts. In this study, very few (14\%) were women, probably because young women, as compared to young men, get less support, are less confident and too dependent to take up business ventures in the rural districts of Tamil Nadu. (Heilbrunn \& Davidovitch 2007) state that in a characteristically male-dominated culture, entrepreneurial opportunities are better suited to men than to women. Plus men take risks much more confidently than women. Although career opportunities for women have increased, typical family roles and domestic commitments continue to remain the responsibility of women. Age is an important aspect of self- development, since resistance to change is relatively little at a young age than when older. Most of the respondents $(86 \%)$ were men, and $73 \%$ were in the age group 30-35. Youngsters are interested in learning and taking risks in life, which is invaluable for entrepreneurship. According to Handi (1973), education is a crucial factor in the running of an enterprise and in becoming an entrepreneur. In this study, only about $33 \%$ of the respondents have completed high school. Consequently, education still remains a priority in development. Since Sivagangai and Ramanathapuram districts are rural areas, $33 \%$ of the respondents' primary occupation is agriculture. The nature of the family typically encompasses nuclear and joint family systems and both display merits and demerits in developing entrepreneurial behavior. Fifty-seven percent of the respondents lived in a joint family, which provides the necessary moral and financial backing for entrepreneurship. Jayapalan (2002) in his book, "Rural Sociology" mentions that the joint family is the backbone of rural life in India, and in this study we see that $50 \%$ of the respondents come from joint families. Income is the most significant factor that influences socio- economic development and empowerment. In this study, the SEPY beneficiaries are from a low socio-economic background, with $36 \%$ drawing an annual income of between Rs.50,001 and 75,000. Enterprise profile of the respondents: An enterprise profile highlights an entrepreneur's enterprise type, year in which it was started, the total investment in the enterprise, and working hours of the entrepreneurs. Most of the respondents (42\%) ran small-scale enterprises. SEPY beneficiaries of TAHDCO from 2014-2016 were taken for the study, and the finding indicates that $40 \%$ of the respondents had established their enterprise in 2015. Twenty-nine percent of the respondents had invested a total of Rs.4-5 lakhs in their business venture. A majority were running travel agencies, while a vast majority $(81 \%)$ were using indigenous rather than foreign technology. Less than half $(41 \%)$ of the respondents were putting in 8-11 hours of work a day, indicating that young entrepreneurs are doing their best to grow and develop their business. There was a gender difference in the type of enterprise undertaken by men and women respondents. Out of the total of 220 men, nearly half (48\%) owned a travels business, compared to merely $6 \%$ of the women respondents. In contrast, of the 35 women respondents, $20 \%$ owned a dairy farm. The SEPY scheme was introduced in 2014, but five percent of the respondents who had started their enterprise in 2013 obtained a loan to extend their business after the implementation of SEPY. Attitude and interest of young entrepreneurs towards entrepreneur ship: Twenty-seven percent of the respondents started an enterprise to bring home an income, given the poverty and unemployment which rural youth are facing today. According to an NSSO survey conducted in 20112012, the unemployment rate in rural areas is lower than in urban areas, largely as a result of self-employment. Less than one- fourth $(22 \%)$ of the respondents were motivated to start something of their own out of sheer interest. Entrepreneurs were aware of the TAHDCO scheme through friends rather than 
family, government officials, banks and NGOs.

Challenges faced by the rural youth entrepreneurs:

Most of the respondents (40\%) said their application took less than 6 months to process, though the project approval time for $28 \%$ was delayed by as much as a year. Forty-two percent of young entrepreneurs faced problems getting their loans sanctioned due to delays by banks, which resulted in their calling off their efforts altogether. Challenges in obtaining capital confronted $34 \%$ of the respondents. With regard to loan repayments, $35 \%$ faced a financial crisis. Sixty percent faced challenges brought on by a lack of education and experience, both of which young rural entrepreneurs lack. Some respondents (23\%) cited the lack of profit as an obstacle in sustaining and expanding their business. There were marketing challenges as well, and $43 \%$ indicated that they were up against tough competition in the market. Young entrepreneurs look to financial institutions, government departments, and voluntary organizations for financial support and training. The gap resulting from a lack of partnership and connectivity with agencies is large. The young entrepreneurs in this study stated that they received helpful moral and financial support from parents and friends. A loan amounting to a total of Rs3-6 lakhs was obtained by $46 \%$ of the respondents, with $51 \%$ receiving a subsidy of Rs 2-2.5 lakhs. Only $28 \%$ have made loan repayments in excess of Rs 3.5 lakhs. The beneficiaries stated that they were unable to repay the loan in full due to slim profit margins. Most opted to run travel agencies, and soon found that they had to contend with frequent road accidents and vehicle repairs, which led to mounting debts. Many declared that they had received no subsidy in the initial stages, while others have yet to receive the subsidy. Respondents who set up their own ventures expressed a desire to upgrade and expand their enterprise.

The Entrepreneur Development Training Programme: Prajapati (2011) suggests that entrepreneurial training programmes focus on the financial, legal and marketing aspects of business. This study observed that an apex body like TAHDCO could not reach out to their youth beneficiaries in implementing training programmes. The Entrepreneur Development Training Programme (EDTP) was created to provide an alternate route to gainful employment for economically disadvantaged individuals through the establishment of their own business. Seventyeight percent of the respondents did not attend the EDTP, and when questioned, stated that no training programme was conducted by TAHDCO. Only 54 out of 255 respondents attended the EDTP, and 68\% did not acquire from the programme the skills and knowledge needed. Sustainability of the business livelihood of the entrepreneurs: In terms of a sustainable livelihood, $60 \%$ of the respondents failed to attain their businesstarget, possibly due to a lack of required skill training and education. Thirty-eight percent made a profit after one year and $51 \%$ found their enterprise profitable enough. A turnover of only between Rs.50,001 and 75,000 was produced by $34 \%$ of the respondents, owing to fluctuations in the business environment. An encouraging note was struck by $51 \%$, who said that the well-being of the enterprise and their employees increased with the passage of time. More than 3/5th (63\%) of the respondents said that

their vulnerability and risks in business decreased after a period of time, and 53\% wanted to expand the business. This finding shows with nearly half of the respondents, the question surrounding the sustainability of their livelihood is still undetermined. On the whole, the TAHDCO scheme has impacted occupation somewhat and led to changes in the beneficiaries' occupation status. Therefore, the researchers have considered occupation as a predominant factor influencing the empowerment of marginalized young beneficiaries in the state.

An Empirical Model of TAHDCO Schemes and Empowerment: A review of the literature on TAHDCO schemes and their implementation in Tamil Nadu has established that financial assistance to (SC/ST)beneficiaries of the Self-Employment Programme for Youth (SEPY)C/ST) has contributed to their development. This scheme found its momentum in empowering the section of society comprising SCs/STs the state level. The SEPY scheme is not very popular among TAHDCO schemes. The empirical evidence in this research clearly indicates that predominant factors such as occupation, education, income, spending patterns, asset building, the savings habit, bank linkage programmes, social contacts, political interaction and cultural changes have significantly impacted the beneficiaries in terms of getting the maximum benefit from the TAHDCO scheme. The empirical analysis also showed that these predominant factors influence the empowerment process of the beneficiaries in the economic, educational, political, social, cultural, environmental and psychological dimensions of empowerment, and have positively impacted the overall development of youth from the SC/ST communities.

\section{SUGGESTIONS}

1. An awareness of TAHDCO schemes among the Scheduled Tribes population is very poor, and only eight tribal youth availed a TAHDCO loan under the SEPY scheme in Sivagangai and Ramanathapuram districts. It is suggested that the government adopts special programmes and campaigns to raise awareness about the schemes.

2. The inadequate publicity generated by TAHDCO is ineffective. Therefore, it is suggested that TAHDCO utilizes mass media like the TV, hoardings, newspaper advertisements, and notice board displays for publicity.

3. It is suggested that procedures for processing loan applications and the extent of support received from bank staff be reasonably relaxed, in line with beneficiaries' requirements. This will attract more beneficiaries who wish to avail the benefits.

4. It is also suggested that the processing and release of the loan amount sanctioned be relaxed as per the individual requirements of beneficiaries, along with with greater support from bank employees. This will encourage them to commence their incomegenerating activities earlier.

5. Most respondents 
prefer loans from public sector banks, though banks in the private sector also offer them. It is suggested that TAHDCO beneficiaries be encouraged to approach private sector banks as well for loans.

6. It is suggested that TAHDCO implements a monitoring system to evaluate beneficiaries' business and income level. Such a system will help banks receive appropriate repayments and get beneficiaries to function better.

7. It is suggested that TAHDCO institutes measures to support beneficiaries by way of enhancing their existing business, creating employment opportunities for others, increasing the volume of business by providing a loan top-up facility, and offering incentives like interest waivers.

8. TAHDCO must take the initiative to provide training to improve beneficiaries' self-education, technical skills, work knowledge and personality. This will enable beneficiaries to function better in every aspect.

9. It is suggested that TAHDCO evaluates beneficiaries' business sat regular intervals till the loan is repaid in full. In this way, the growth and development of beneficiaries can be speeded up by helping them create fixed assets, making new investments, inculcating the habit of saving, and sharing information on various schemes related to investments and savings.

10. It is suggested that TAHDCO motivates beneficiaries who repay loans promptly by providing them additional benefits and creating opportunities for them to avail additional loans from the bank.

11. In general, it can be said that TAHDCO schemes have moderately impacted beneficiaries' socioeconomic developmental ventures, such as occupation, income- generation and asset-building. Hence, it is suggested that TAHDCO concentrates more on selecting viable projects for beneficiaries that will enhance the undertakings listed above and ultimately enhance their socio- economic standing in society.

12. The result shows that the empowerment so far, in real terms, has been rather modest in the case of TAHDCO beneficiaries, which indicates that a meticulous screening of TAHDCO schemes is essential to bring about real empowerment among the SC/ST population.

13. The beneficiaries felt that the loan sanctioned is somewhat small when compared to the market price; hence, TAHDCO must consider this and accordingly upgrade its financial assistance for this particular scheme. TAHDCO must have competent and skilled staff, through a proper screening process, before sanctioning financial assistance to beneficiaries. There is a lack of understanding between the bank and TAHDCO, and the resultant delay in the release of the loan causes beneficiaries a great deal of hardship. It is essential for both banks and TAHDCO to follow procedures and regulations which will help them protect the interests of beneficiaries and enhance their success. Given the lack of awareness in the urban SC/ST population, TAHDCO and the government must publicize their schemes adequately.

\section{CONCLUSION}

Global development is entering a phase where entrepreneurship will increasingly play a major role. The need for economies to encourage growth through sustainable access to resources, and through innovative ideas, is imperative. In a country like India, the population is made up of young people with immense potential for entrepreneurial ventures.

Despite the fact that the TAHDCO scheme benefits young entrepreneurs, there are loopholes in government policies resulting from a lack of supervision and an evaluation of the policies implemented, which renders the scheme ineffective. A few problems with the scheme included

- delays in providing entrepreneurs a subsidy and a loan;

- the subsidy not being offered alongside the loan; and

- the fact that the entrepreneurs had, of necessity, to repay the loan in full to receive the subsidy.

Hence, policies must be revised to favor these young entrepreneurs. After the implementation of the TAHDCO scheme, there has been no proper follow-up to check on whether young entrepreneurs have benefited financially. Further, this study makes it clear that no entrepreneurship training programme was conducted for TAHDCO beneficiaries who received loans during 2014-2016. Young entrepreneurs faced major challenges in sustaining their business livelihood, making profits, and coping with market challenges. If these entrepreneurs are offered appropriate training programmes with much- needed skills and knowledge, it will help them make a profit and sustain their business with an improved livelihood. This was a major drawback of the TAHDCO scheme identified in the study. Minimizing and simplifying regulatory and administrative procedures, as well asmaximizing the support needed to comply with them, will make it easier for young people to set up and run their businesses. Entrepreneurial challenges differ from each other, based on the nature, location, and products or services offered. Based on the findings, the researchers havemade a few suggestions for the development of entrepreneurship. It can be materialized through joint ventures among entrepreneurs, ground-level support in terms of awareness, training, encouragement and support from non-governmental organisations and local institutions, with financial assistance and other promotional intervention from government departments. The development of entrepreneurship can contribute to the growth in the per capita income and foster steady economic growth and not merely among marginalized youth. The economy of the state and nation can be strengthened as well. 


\section{ACKNOWLEDGEMENT}

The Author Dr.C.Vethirajan, Professor and Head, Department of Corporate Secretaryship, School of Management, Alagappa University, Karaikudi has greatly acknowledged under RUSA Phase 2.0 Scheme and the Corresponding Authors also acknowledged the same.

\section{REFERENCES}

1. Adam Fletcher (2015).A Short Intro to Youth Engagement in the Economy: The Free Child Project, PO Box 6185, Washington,USA: Olympia.

2. Alvarez, Sharon \& Barney, Jay B. (December, 2007). Discovery and Creation: Alternative Theories of Entrepreneurship Action, Strategic Entrepreneurship Journal, DOI: 10.10002/sej-4.

3. Ajay Nayar\&Vasanth Kiran (2012). Entrepreneurship: Problems and Challenges Faced, Journal of Entrepreneurship \& Management.

4. Chambers, Robert and Gordon Conway (1991). Sustainable Entrepreneurship in Rural Livelihood,accessed from www.springer.com/content/document.

5. Charles Viereck (2005). Sustainable Entrepreneurship: The Motivations and Challenges of Sustainable Entrepreneurs in theRenewal Energy Industry. Jonkoping International Business School, 2012.

6. Clemensson, Martin (2010). How to Build an Enabling Environment for Youth Entrepreneurship and Sustainable Enterprise. Geneva: International Labour Organisation (ILO).

7. David N.F. Bell (November 27th, 2009), Youth Unemployment: Déjà $\mathrm{Vu}$ ? Division of Economics, Stirling Management School, University of Stirling and IZA.

8. Endeavor Insight (2016). How Does Corruption Impact Entrepreneur ship?,accessed from www.ecosystem insights.org.

9. European Open Business \& Management Journal, Vol. 1, No.1, April 2015, pp1- 10.

10. Guta, Gerald, George Vhudzi\& Bernard Chazovachii (January 2017). Sustainability of Rural Entrepreneurship as a Livelihood Strategy in Zaka District, Zimbabwe, Bangladesh e-Journal of Sociology, Volume 14, Number 1.

11. Fernando, Pacheco-Torgal, Erik Stavnsager Rasmussen, Claes G.Granqvist, Volodymyr Ivanov, HabilArturas Kaklauskas\& StephenMakonin (2016). Start-Up Creation: The Smart Eco- efficient Built Environment,UK: Elsevier Ltd. - Woodhead Publishing Series in Civil and Structural Engineering: Number66.

12. Gartner, William \& Baker, Ted (2010). A Plausible History and Exploration of Stevenson's Definition of Entrepreneurship, Clemson University, Frontiers of Entrepreneurship Research: Vol.30:Iss.4, Article 2.

13. Israel Dessalegne (January 2013). Opportunities and Constraints to Youth Entrepreneurship: Perspectives of Young Entrepreneurs in Swaziland. United Nations study, Swaziland.

14. Jayashree Suresh (2009). Entrepreneurial Development. Chennai: Margham Publications.

15. Kanbur (1979), cited in Naude, Wim (2013). Entrepreneurship and Economic Development Theory, Evidence and Policy, Discussion Paper No. 7507, Germany.

16. Karen Ellis \&Carolin Williams (March 2011). MaximisingImpact of Youth Entrepreneurship Support in Different Contexts. UK: Overseas Development Institute.

17. Khanka, S.S. (2009).Entrepreneurship in India: Perspective and Pr a c t i ce. In dia: A k a n sha Public a tions, IS B N 10:8183701930/ISBN 13: 9788183701938.

18. Khanka, S.S. (1999). Entrepreneurial Development. New Delhi: S. Chand \& Company.

19. Landstrom, Hans (2005). Pioneers in Entrepreneurship and Small Business Research, ISEN International Studies in Entrepreneurship. Boston: Springer.

20. Manimala, M.J., Gopal, M.V., Prakhya, S. \& Shields, J. (2001). India Report 2001. Global Entrepreneurship Monitor, NS Raghavan Centre for Entrepreneurial Learning, Indian Institute of Management, Bangalore, India.

21. Ministry of Youth Affairs \& Sports, Government of India (2014). National Youth Policy 2014 Document.

22. Monday Osemeke (Special Issue, April 2012). Entrepreneurial Development and Interventionist Agencies in Nigeria, International Journal of Business and Social Sciences, Vol.3, No.8.

23. Naude, Wim(2010). Entrepreneurship, Developing Countries and Development Economics, Small Business Economics, Springer, Volume 34,Issue 1.

24. Naude, Wim (2013). Entrepreneurship and Economic Development Theory, Evidence and Policy, Discussion Paper No. 7507, Germany.

25. Organization for Economic Co-operation and Development (OECD),Annual Report from the Public Affairs and Communications Directorate (2003), accessed from www.tedtea.org.

26. Poonam Barhoi (0ct 2016). Need for Entrepreneurship in India.Report of the National Sample Survey Organization.

27. Rocha, Hector (2004). Entrepreneurship and Development: The Role of Clusters, Small Business Economics, Vol.23, issue 5, pp. 363- 400.

28. Shashank Mani(Nov 18,2013). How Youth Entrepreneurs Bring Hope and Enterprise to India, United Nations Development Programme, UNDP Youth Strategy 2014-2017, Empowered Youth Sustainable Future.

29. Tamil Nadu AdiDravidar Housing and Development Corporation TAHDCO Scheme, accessed from www.tahdco.tn.gov.in.

30. Ulrich Schoof (2006). Stimulating Youth Entrepreneurship: Barriers and Incentives to Enterprise Start-ups by Young People, Series on Youth and Entrepreneurship (SEED Working Paper No. 76). International Labour Office, Geneva.

31. UNESCO (2014).Taken from http://www.UNESCO.org/ new/en/ social andhuman sciences/Themes

32. Venkatachalam \&Warif (2005), cited in the study Entrepreneurship Education in India: A Critical Assessment and Proposed Framework (Rituparna Basu, 2014), Technology Innovation Management Review.

33. World Business Council for Sustainable Development's definition of sustainable entrepreneurship, cited in the study Sustainable Entrepreneurship and Knowledge-based Development (Surinder Batra). Institute of Management Technology, Ghaziabad, India.

34. Yellen, Janet (2017). Quotation accessed fromhttps://www. brainyquote.com/quotes/quotes/j/Janet yelle800715.html.

35. Zhenzhong Ma, Tangting Wang \&Yender Lee (2012). The Status of International Ethnic Entrepreneurship Studies: A Co-citation Analysis, Journal of Entrepreneurship, Vol. 21, Issue 2, 173-19

36. Adam Fletcher (2015).A Short Intro to Youth Engagement in the Economy: The Free Child Project, PO Box 6185, Washington,USA: Olympia.

37. Alvarez, Sharon \& Barney, Jay B. (December, 2007). Discovery and Creation: Alternative Theories of Entrepreneurship Action, Strategic Entrepreneurship Journal, DOI: $10.10002 / \mathrm{sej}-4$.

38. Ajay Nayar\&Vasanth Kiran (2012). Entrepreneurship: Problems and Challenges Faced, Journal of Entrepreneurship \& Management.

39. Charles Viereck (2005). Sustainable Entrepreneurship: The Motivations and Challenges of Sustainable Entrepreneurs in the Renewal Energy Industry. Jonkoping International Business School, 2012.

40. Clemensson, Martin (2010). How to Build an Enabling Environment for Youth Entrepreneurship and Sustainable Enterprise. Geneva: International Labour Organisation (ILO).

41. David N.F. Bell (November 27th, 2009), Youth Unemployment: Déjà Vu? Division of Economics, Stirling Management School, University of Stirling and IZA.

42. Endeavor Insight (2016). How Does Corruption Impact Entrepreneur ship?,accessed from www.ecosystem insights.org.

43. European Open Business \& Management Journal, Vol. 1, No.1, April 2015, pp1- 10 .

44. Guta, Gerald, George Vhudzi\& Bernard Chazovachii (January 2017). Sustainability of Rural Entrepreneurship as a Livelihood Strategy in Zaka District, Zimbabwe, Bangladesh e-Journal of Sociology, Volume 14, Number 1.

45. Fernando, Pacheco-Torgal, Erik Stavnsager Rasmussen, Claes G.Granqvist, Volodymyr Ivanov, HabilArturas Kaklauskas\& StephenMakonin (2016). Start-Up Creation: The Smart Eco- efficient Built Environment,UK: Elsevier Ltd. - Woodhead Publishing Series in Civil and Structural Engineering: Number66.

46. Gartner, William \& Baker, Ted (2010). A Plausible History and Exploration of Stevenson's Definition of Entrepreneurship, Clemson University, Frontiers of Entrepreneurship Research: Vol.30:Iss.4, Article 2.

47. Indian Institute of Entrepreneurship, Management, and Technology (2017).Igniting the Entrepreneurial Spirit of India, accessed from www.iiemt.org.

48. Israel Dessalegne (January 2013). Opportunities and Constraints to Youth Entrepreneurship: Perspectives of Young Entrepreneurs in Swaziland. United Nations study, Swaziland.

49. Jayashree Suresh (2009). Entrepreneurial Development. Chennai: Margham Publications.

50. Kanbur (1979), cited in Naude, Wim (2013) Entrepreneurship and 
Economic Development Theory, Evidence and Policy, Discussion Paper No. 7507, Germany.

51. Karen Ellis \&Carolin Williams (March 2011). MaximisingImpact of Youth Entrepreneurship Support in Different Contexts. UK: Overseas Development Institute.

52. Ministry of Youth Affairs \& Sports, Government of India (2014)

53. National Youth Policy 2014 Document

54. Monday Osemeke (Special Issue, April 2012). Entrepreneurial Development and Interventionist Agencies in Nigeria, International Journal of Business and Social Sciences, Vol.3, No.8.

55. Naude, Wim(2010). Entrepreneurship, Developing Countries and Development Economics, Small Business Economics, Springer, Volume 34,Issue 1.

56. Naude, Wim (2013). Entrepreneurship and Economic Development Theory, Evidence and Policy, Discussion Paper No. 7507, Germany.

57. Organization for Economic Co-operation and Development (OECD),Annual Report from the Public Affairs and Communications Directorate (2003), accessed from www.tedtea.org.

58. Poonam Barhoi (0ct 2016). Need for Entrepreneurship in India.Report of the National Sample Survey Organization.

59. Shashank Mani(Nov 18,2013). How Youth Entrepreneurs Bring Hope and Enterprise to India, United Nations Development Programme, UNDP Youth Strategy 2014-2017, Empowered Youth Sustainable Future.

60. Tamil Nadu AdiDravidar Housing and Development Corporation TAHDCO Scheme, accessed from www.tahdco.tn.gov.in

61. Ulrich Schoof (2006). Stimulating Youth Entrepreneurship: Barriers and Incentives to Enterprise Start-ups by Young People, Series on Youth and Entrepreneurship (SEED Working Paper No. 76). International Labour Office, Geneva.

62. UNESCO (2014).Taken from http://www.UNESCO.org/ new/en/ social andhuman sciences/Themes

63. World Business Council for Sustainable Development's definition of sustainable entrepreneurship, cited in the study Sustainable Entrepreneurship and Knowledge-based Development (Surinder Batra). Institute of Management Technology, Ghaziabad, India.

64. Yellen, Janet (2017). Quotation accessed fromhttps://www.brainyquote.com/quotes/quotes/j/Janet yelle800715.html.

65. Zhenzhong Ma, Tangting Wang \&Yender Lee (2012). The Status of International Ethnic Entrepreneurship Studies: A Co-citation Analysis, Journal of Entrepreneurship, Vol. 21, Issue 2, 173-19F

\section{AUTHOR PEOFILE}

Prof. (Dr.) C.Vethirajan is Professor and Head in the Department of Corporate Secretaryship, School of Management, Alagappa University, Karaikudi, Tamil Nadu. He has received UGC Research Award (20142016). He has 24 years of standing in his academic career. He has published papers in international journals of repute and he is also serving as a reviewer of international journals.

Dr. S. Chandrasekar is Assistant Professor in the Department of Commerce, Madura College (Autonomous), Madurai, Tamilnadu.

Mr. MK.Ganeshan is a full time Ph.D., Research Scholar in the Alagappa Institute of Management, School of Management, Alagappa University, Karaikudi, Tamil Nadu. 